\title{
Recenzja
}

\section{„Zagadnienia Sądownictwa Konstytucyjnego” 2011, nr 1 i 2, czasopismo naukowe Biura Trybunału Konstytucyjnego}

„Zagadnienia Sądownictwa Konstytucyjnego” (ZSK) są nowym pismem prawniczym, powstałym $\mathrm{z}$ inicjatywy pracowników Biura Trybunału Konstytucyjnego i przez Biuro Trybunału wydawanym. Numer pierwszy ukazał się w 2011 r., numer drugi na początku 2012 r.

W pierwszym numerze zamieszczone zostały przez Zespół Redakcyjny Informacje wstępne stanowiące uzasadnienie powstania tej nowej inicjatywy wydawniczej i określenie projektowanego profilu pisma. W tej krótkiej nocie redaktorzy ZSK wskazali, iż nowa inicjatywa jest reakcją na potrzebę podjęcia szerszej dyskusji nad problemami sądownictwa konstytucyjnego w zakresie zagadnień podstawowych (m.in. pozycja ustrojowa sądu konstytucyjnego), przekrojowych (problemy na pograniczu teorii prawa, prawa konstytucyjnego i innych gałęzi prawa), a także szczegółowych, wynikających z orzeczeń Trybunału i innych sądów konstytucyjnych. Wyrażonym wprost zamiarem Zespołu Redakcyjnego jest stworzenie na łamach ZSK płaszczyzny wymiany poglądów na temat problemów sądownictwa konstytucyjnego. Warto tu też wskazać, że zaproszenie do współpracy adresowane jest nie tylko do specjalistów z prawa konstytucyjnego, ale wszystkich osób, które w swej działalności zawodowej stykają się z problematyką kontroli konstytucyjności prawa.

Jak widać, ambicje pomysłodawców i redaktorów pisma dalece wykraczają poza formułę biuletynu wspomagającego pracę Trybunału i skupionego na analizie orzecznictwa, którego przykładem może być coroczny Constitutional Court Review poświęcony działalności Sądu Konstytucyjnego RPA (skądinąd stopniowo wykraczający poza te ramy). Inicjatywa zespołu skupionego w Biurze Trybunału Konstytucyjnego jest wyrazem dążenia do wzbogacenia rynku wydawniczego o pismo par excellence naukowe, ale nie hermetyczne. Nasuwa się tu więc chwalebne porównanie do „Przeglądu Sejmowego", który od pierwszego numeru sprzed blisko 20 lat postawił sobie za 
cel wspomaganie rozwoju polskiego systemu parlamentarnego i krytyczne rozważania nad parlamentaryzmem. Choć w Informacjach wstępnych ZSK nie padają słowa o krytycznych rozważaniach, tak odczytuję kilkakrotnie powtórzony przez Zespół Redakcyjny zwrot o „szerszej dyskusji”. Obrany kierunek jest zatem wielce trafny i skłania do zachęcania Redakcji do konsekwentnej realizacji przedstawionych zamierzeń.

Nie można tu pominąć szczególnego podłoża instytucjonalnego, jakim jest afiliacja nowego pisma ze stabilnym, autonomicznym organem konstytucyjnym w postaci Trybunału Konstytucyjnego. Otwiera się tu szansa na zabezpieczenie równie stabilnego funkcjonowania ZSK i jego długofalowy rozwój. Bliski związek z Trybunałem stawia natomiast przed Zespołem Redakcyjnym wyzwanie co do tego, czy i w jakim zakresie „Zagadnienia Sądownictwa Konstytucyjnego" pozostaną pismem w obrębie dominującego obecnie, szczególnie w polskiej doktrynie, nurtu „nowego konstytucjonalizmu” czy też ,jurystokracji”, który polega na podważaniu władzy parlamentów oraz wzmacnianiu pozycji ustrojowej sędziów i sądów konstytucyjnych. Naturalnie zrozumiałe i wartościowe samo z siebie byłoby stworzenie w ZSK przez środowisko intelektualne związane z Trybunałem Konstytucyjnym mocnego głosu polskiej wersji nowego konstytucjonalizmu, ale jeszcze silniej mogłaby wpłynąć wspólnota twórców ZSK na rozwój nauki w tym obszarze, gdyby ZSK podejmowało również próbę transgresji, reinterpretacji sądownictwa konstytucyjnego, w nawiązaniu do poglądów takich badaczy jak Ran Hirschl, Wojciech Sadurski czy Mark Tushnet. Za zapowiedź podjęcia takich rozważań można uznać wyrażenie w Informacjach wstępnych pragnienia podjęcia dyskusji także nad relacją sądów konstytucyjnych do innych organów władzy publicznej i legitymizacji sędziów.

Dwa wydane już numery pozwalają na wstępną ocenę nowego pisma, przynajmniej w jego stadium początkowym. Mamy do czynienia z czasopismem, które można uznać za periodyk, bowiem zachowana jest stała numeracja, oba numery formalnie datowane są na 2011 r., utrzymana jest też bliźniacza struktura pisma. Odnotować należy, że w drugim numerze poszerzeniu uległ Komitet Redakcyjny (z 8 do 11 członków), od drugiego numeru funkcję Redaktora Naczelnego pełni prof. Paweł Wiliński, który zastąpił prof. Piotra Tuleję, w Komitecie zasiada dwóch sędziów Trybunału, tj. prof. Stanisław Biernat i wspomniany prof. Tuleja. 
Oba numery mają poręczny format, są porządnie edytorsko opracowane, liczą ponad 200 stron. ZSK podzielone jest na cztery działy: Studia i artykuły; Przegląd orzecznictwa Trybunału Konstytucyjnego i innych sądów; Recenzje, sprawozdania, varia; Bibliografia opracowań i adnotowany przegląd zawartości czasopism o tematyce sądownictwa konstytucyjnego. W podziale tym pierwszoplanowo potraktowane zostały studia i artykuły, czego wyrazem jest to, że przeważają one objętościowo nad pozostałymi działami. W sumie dorobek pisma obejmuje już 12 artykułów naukowych od dziesięciorga autorów. Drugi, mniej obszerny dział poświęcony jest przeglądowi orzecznictwa (w sumie 8 tekstów). Te proporcje uważam za dobre, realizujące wspomniane ambicje twórców periodyku przedstawiania czytelnikom nie tylko opracowań pomocniczych, przeglądowych, ale też wyeksponowanych na początku numeru tekstów problemowych i dyskursywnych. Wśród nich warto zwłaszcza zwrócić uwagę na dwa głębokie artykuły R. Piotrowskiego: Wartości i polityka. Refleksje o dysfunkcjonalnej praktyce konstytucyjnej oraz Globalizacja i konstytucja. Oba są bardzo aktualne, pełne wynikających z erudycji Autora refleksji równie inspirujących, co - nierzadko - gorzkich. Oba też stanowią ozdobę numerów.

Dostrzegalnym nurtem, zwłaszcza w drugim numerze, są teksty wykraczające poza polskie sądownictwo konstytucyjne. A. Wołoszczak podejmuje temat Formalizmu sędziowskiego jako granicy możliwości prawotwórczych sędziego, argumentując w swym tekście m.in. na rzecz niepozytywistycznej koncepcji państwa prawa i krytycznie przedstawiając argumenty przeciwników prawotwórstwa sędziów. Popularyzowany niestrudzenie przez K. Complaka dorobek ustrojowy krajów Ameryki Południowej i Środkowej znajduje wyraz w tekście Autora poświęconym Godności człowieka w wyrokach sądów konstytucyjnych Latynoameryki, w którym warto m.in. zwrócić uwagę na interesujący wątek nieznanych w Europie procedur ochrony praw jednostki, a także związku godności z zagadnieniami polityki praktyki kryminalnej w omawianych państwach. W artykule Podatek liniowy w Polsce a doświadczenia krajów regionu M. Nowak prezentuje zaś zasadność wprowadzenia w Polsce powszechnego podatku liniowego, korzystając z doświadczeń m.in. Rosji i Ukrainy.

Nie zaskakuje okoliczność, iż większość prezentowanych artykułów poświęcona jest zagadnieniom związanym $\mathrm{z}$ działalnością Trybunału Konstytucyjnego. A. Syryt i B. Majchrzak w obszernym opracowaniu zajmują się 
problemem dopuszczalności kontroli miejscowego planu zagospodarowania przestrzennego przez Trybunał Konstytucyjny, prowadząc czytelnika w wyważonej argumentacji do konkluzji, iż plan miejscowy ma charakter aktu normatywnego, ale przyczyny celowościowe i systemowe przemawiają za wyłączeniem kognicji Trybunału w tym zakresie. Realizując zamiar Redakcji eksplorowania w ZSK problemów rodzących się na styku prawa konstytucyjnego i innych gałęzi prawa, analizuje B. Nita w swoim artykule Zakaz podwójnego karania $w$ ujęciu konstytucyjnym ową kanoniczną zasadę procesu karnego, niewyrażoną wprost w Konstytucji RP, oraz trudności w jej stosowaniu przez TK. A. Wołoszczak, odwołując się do dorobku Trybunału, omawia niespójne gwarancje własności w Konstytucji RP. B. Majchrzak $\mathrm{w}$ artykule Dostęp do informacji publicznej zawartej $w$ aktach sprawy rozpatrywanej przez Trybunał Konstytucyjny zajmuje się wnikliwie niełatwymi i subtelnymi relacjami między ustawą o dostępie do informacji publicznej a ustawą o Trybunale Konstytucyjnym. Natomiast w tekście A. Kustry Legitymacja podmiotów publicznych do wniesienia skargi konstytucyjnej Autorka dokonuje podsumowania dotychczasowego orzecznictwa w tej kontrowersyjnej, tytułowej kwestii, wytyka brak konsekwencji Trybunału i przedstawia krytykę nieuznawania przez Trybunał zdolności skargowej podmiotów publicznych.

Przejawem dopracowywania koncepcji pisma i świadomego doboru treści jest trafne zamieszczenie $\mathrm{w}$ drugim numerze opracowania I. Chojnackiej Granice działalności ustawodawczej $w$ stanowieniu prawa $w$ orzecznictwie Trybunału Konstytucyjnego w dziale drugim, bo stanowi ono przegląd orzecznictwa TK, natomiast w numerze pierwszym tekst tej Autorki o podobnej formule, Zasada przyzwoitej legislacji $w$ orzecznictwie Trybunału Konstytucyjnego znajdował się w pierwszym dziale studiów i artykułów. Niezależnie od autonomicznej wartości opracowań przeglądowych, syntetyzujących orzecznictwo i ułatwiających jego badanie, postulować należy utrzymanie ściślejszej selekcji tekstów i zamieszczanie $\mathrm{w}$ dziale studiów tych pracochłonnych tekstów, które w znacznym stopniu zawierają autorskie pierwiastki intelektualne, a w których dorobek orzeczniczy jest podstawą do formułowania własnych refleksji. Przykładem takiego artykułu, niewymienionym wcześniej, jest opracowanie J. Królikowskiego Zasada falsa demonstratio non nocet $w$ postępowaniu przed Trybunałem Konstytucyjnym, w którym wnikliwa analiza orzeczeń przywołujących tytułową formułę pozwala 
Autorowi na przeprowadzenie wzorowo uporządkowanego, wielopłaszczyznowego wywodu.

To krótkie wyliczenie artykułów problemowych zamieszczonych w dwóch pierwszych numerach ZSK pokazuje, że z powodzeniem realizowane są zamierzenia Zespołu Redakcyjnego dotyczące stworzenia w periodyku płaszczyzny wymiany poglądów. Nie brakuje tekstów wyrazistych, pobudzających do refleksji (zwłaszcza artykuły R. Piotrowskiego), zachęcających do polemik (myślę tu szczególnie o żywej, mieszczącej się w nurcie „nowego konstytucjonalizmu" argumentacji A. Wołoszczak na rzecz prawotwórstwa sądów), krytycznych wobec orzeczeń TK (m.in. zastrzeżenia A. Kustry wobec sumiennie ujętych przez Autorkę tez Trybunału), zgłębiających słabo rozpoznane problemy na pograniczu prawa konstytucyjnego (reguła budowana przez B. Majchrzaka na tle kolizji ustawy o TK i ustawy o dostępie do informacji publicznej).

W dziale poświęconym przeglądowi orzecznictwa dominują teksty poświęcone problematyce sądów konstytucyjnych państw obcych, m.in. RFN i Rosji. Wśród opracowań przeglądowych wyróżnia się dłuższe omówienie J. Pawliczaka poświęcone orzecznictwu TK w sprawie sankcji procesowych stosowanych a limine w postępowaniu cywilnym. Jest to bardzo przejrzyste, pogłębione omówienie, w którym Autor m.in. starannie przedstawia dostrzeżone przez siebie niespójności i nieodpowiednie założenia przyjmowane przez Trybunał dla oceny omówionych spraw.

Interesująco kształtowany jest trzeci dział Recenzja, sprawozdania, varia. $\mathrm{W}$ numerze pierwszym zamieszczono $\mathrm{w}$ nim sprawozdanie $\mathrm{z}$ konferencji z 2006 r., a w numerze drugim opracowanie dotyczące badania konstytucyjności ustaw w międzywojennej Czechosłowacji oraz sprawozdanie z Kongresu Konferencji Europejskich Sądów Konstytucyjnych z 2011 r. W pełni podzielam ocenę Redakcji, iż sprawozdanie z dyskusji z 2006 r. odbytej w ramach Konferencji Trybunału Konstytucyjnego i Komitetu Nauk Prawnych PAN zasługiwało na udostępnienie szerszym rzeszom czytelników i utrwalenie na łamach periodyku. Jest to kilkadziesiąt stron zajmującej i wartościowej lektury na temat polityki i sądownictwa konstytucyjnego, a okoliczność, że dyskusja odbyła się pięć lat przed publikacją, w żaden sposób nie umniejsza wartości płynącej z jej utrwalenia. Szeroka formuła działu mogłaby też zachęcić do sięgnięcia do stricte historycznych, słabiej znanych materiałów dotyczących sądownictwa konstytucyjnego, na przykład refleksji polskich 
uczonych z okresu międzywojnia, badaczy z obszaru niemieckojęzycznego, czy też klasyków anglosaskich, np. spuścizny Olivera Wendella Holmesa, Jr.

Ostatni dział ma charakter bibliograficzny. Piotr Sobczyk prowadzi w nim wybraną bibliografię pozycji dotyczących Trybunału Konstytucyjnego. Nie zostało to wprost ujęte, ale mimo że w pierwszym numerze bibliografia obejmuje, zgodnie z tytułem, okres od lipca 2009 do czerwca 2010 r., a w drugim numerze okres 2011 r., mamy prawdopodobnie do czynienia z ciągłą obserwacją publikacji dotyczących Trybunału, ponieważ bibliografia w drugim numerze obejmuje też pozycje z datą wydania w $2010 \mathrm{r}$.

Osobno pragnę zwrócić uwagę na prowadzony przez Marcina Zielińskiego przegląd artykułów z pism obcojęzycznych. Dla wielu czytelników może to być element, od którego rozpoczyna się lekturę pisma. Obszerne omówienia przygotowane przez M. Zielińskiego pisane są przystępnie, ze znawstwem i widocznym zaangażowaniem. Szkoda tylko, że w drugim numerze przegląd artykułów jest wyraźnie krótszy w stosunku do pierwszego numeru.

Dwa pierwsze numery „Zagadnień Sądownictwa Konstytucyjnego” skłaniają do wyrażenia uznania dla Zespołu Redakcyjnego i grona autorów (przy części nazwisk można zaryzykować stwierdzenie, że są to już stali współpracownicy pisma) oraz życzenia utrzymania poziomu w przyszłości i dalszego, wieloletniego rozwoju. Sądzę, że Redakcja trafnie utrzymuje równowagę między naukowym a użytkowym charakterem pisma, wzbogacającego refleksję na temat szeroko rozumianego sądownictwa konstytucyjnego, $\mathrm{z}$ równoległym istotnym komponentem utylitarnym (przeglądy, sprawozdania, bibliografia). Również planowaną częstotliwość wydawania ZSK jako półrocznika, co pozwala na oczekiwanie dwóch kolejnych numerów datowanych na 2012 r., uznaję za właściwy wybór. Pozwala on na cykliczny kontakt z czytelnikami, a ułatwia selekcję wartościowych tekstów bez nadmiernej presji czasu. Poziom pisma powinien też zachęcić Zespół Redakcyjny do starań o zapewnienie jak najłatwiejszego dostęp do niego, jeśli nie w postaci całych numerów dostępnych w Internecie, to co najmniej w postaci spisu treści i abstraktów (przykładem „Zeszyty Naukowe Sądownictwa Administracyjnego").

Sebastian Kubas

(Uniwersytet Jagielloński w Krakowie) 